DUELL, R. -1983- Bryologische Beitraege. 2. Arbeitsgruppe Bryologie Duisburg.

GONZALEZ FRAGOSO, R. -1883- Apuntes para la flora de la provincia de Sevilla. Anal. Soc. Esp. Hist. Nat. Madrid, 12:14-23.

JOVET-AST, S \& BISCHLER, H. -1967- Riccia crustata Trab., nouveau pour l'Europe. Riccia sommieri Lev., nouveau pour l'Espagne. Rev. Bryol. Lichénol. Paris, 35:385.

JOVET-AST, S \& BISCHLER, H. -1969- Distribution, écologie, sociologie du Riccia perennis Stp. Rev. Bryol. Lichénol. Paris, 37, 2:247-264.

JOVET-AST, S. \& BISCHLER,. H. -1976- Hépatiques de la Péninsule Ibérique: énumeration, notes écologiques. Rev. Bryol. Lichénol. Paris, 42, 4:941-987.

MULLER, P.K. -1954- Die Lebermoose Európas. Leipzig. Yohuson. Reprint Corporation. New-York-London, 1-1365.

OLIVA, R. -1987- Catálogo de Hepáticas de Andalucía Occidental. I. Córdoba. Actas VI Simp. Nac. Bot. Crip. Granada.

(Aceptado para su publicación el 23 de septiembre de 1987)

Dirección de la autora: Avda. Conde de Vallellano, 8. 14004, Córdoba.

\title{
MELILOTUS SPECIOSA DUR. IN EUROPE
}

\author{
M. THULIN
}

RESUMEN: Se cita por primera vez para el Sur de España Melilotus speciosa, especie tan sólo conocida hasta el momento del Noroeste de Africa.

SUMmaRY: Melilotus speciosa, previously known only from north-western Africa, is reported from southern Spain.

Melilotus speciosa Dur. in Duchartre, Rev. Bot. 1:365 (1845). Spain. Andalucía. Málaga Prov.: Cueva de la Pileta, W of Ronda, 30 May 1983, M. Thulin 4797 (UPS).

This is apparently the first record for Europe of this otherwise north-west African species. The new locality is in a much visited area near the entrance of the Pileta cave and the 


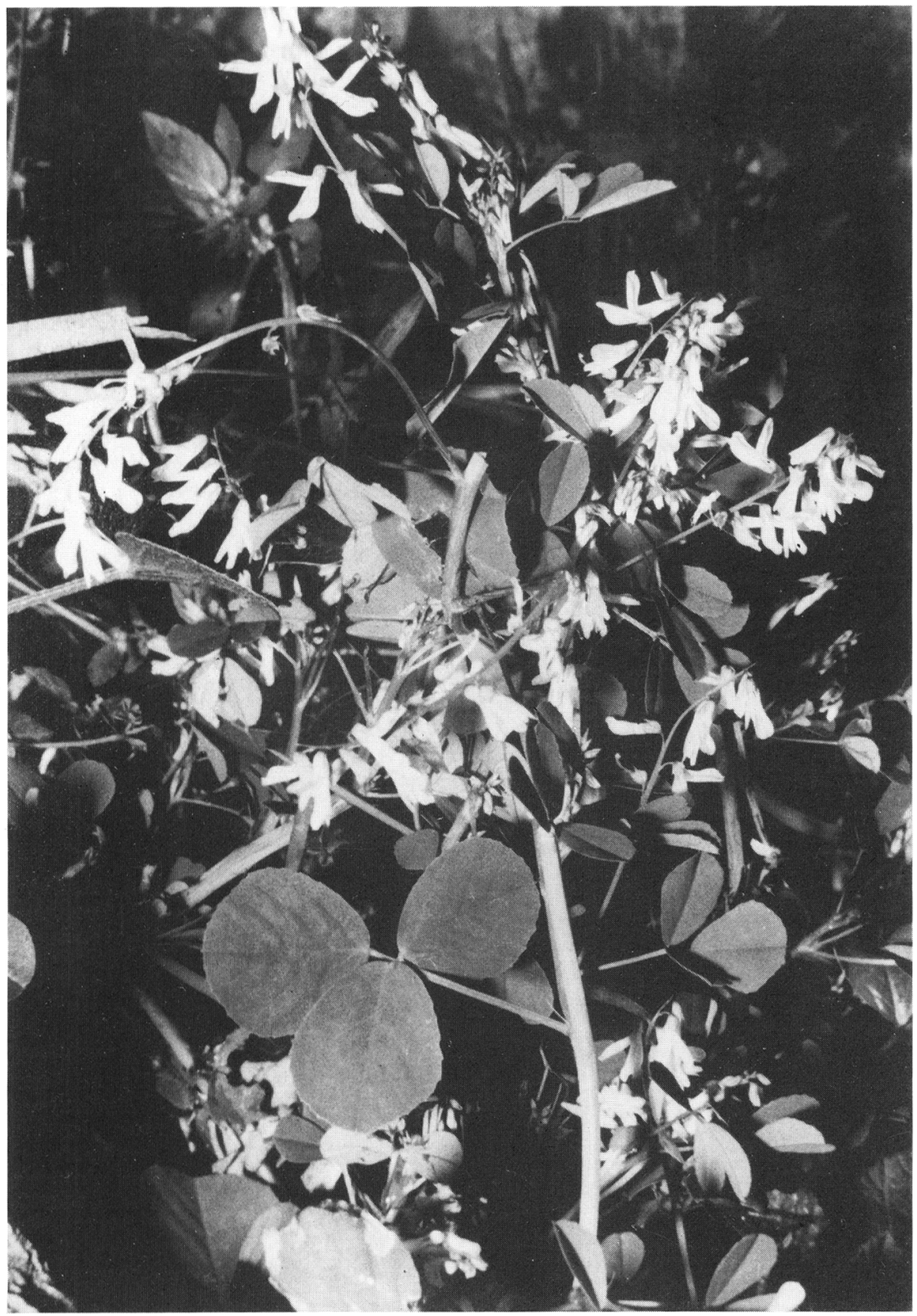

Figure 1.- Melilotus speciosa in the Locality near Cueva de la Pileta; 14 May 1984. - Photo S. Iversen. 
possibility that the plant has been introduced lately cannot be excluded. However, the species grows in natural vegetation on limestone rocks. Plants in the vicinity include Omphalodes commutata, Rubia peregrina, Linaria platycalyx, Scilla peruviana, Jasminum fruticans, Fumaria capreolata and Euphorbia pinea. The altitude is ca. $810 \mathrm{~m}$. The place was visited also during an excursion in May 1984, and the species was then still present.

The white-flowered M. speciosa is immediately distinguished from other European species with white flowers by its incised-dentate stipules and 1arger, 7-8 mm long corolla. The species is known previously only from Morocco and northern Algeria.

\title{
COMENTARIOS SOBRE ALGUNAS PLANTAS NUEVAS PARA LA FLORA DE AVILA, ESPAÑA
}

\author{
María Andrea CARRASCO \& Javier ESTRADA
}

RESUMEN: Se presentan siete taxones nuevos para la flora de Avila, incluyendo algunos comentarios sobre su distribución en el centro peninsular.

SUMMARY: In this paper, seven taxa recorded for the first time from Avila province are listed. We present also, some commentaries about its distribution in the centre-west of Spain.

Con objeto de aportar datos para el mejor conocimiento de la flora vascular del centro de la peninsula, hemos realizado herborizaciones al suroeste del Sistema Central, en la cuenca alta del rio Corneja, tributarió del Tormes, perteneciente a la Cuenca del Duero.

E1 territorio se sitúa en el sector Cornejano-Amblense de la provincia corológica Carpetano-Ibérico-Leonesa, a altitudes que oscilan entre 1000 y 1600 m.s.m., con una oscilación térmica anual superior a $20^{\circ} \mathrm{C}$, lo que nos indica la 